University of California, Hastings College of the Law UC Hastings Scholarship Repository

Faculty Scholarship

1981

\title{
Reliance in the Revised Restatement: The Proliferation of Promissory Estoppel
}

Charles L. Knapp

UC Hastings College of the Law, knappch@uchastings.edu

Follow this and additional works at: http://repository.uchastings.edu/faculty_scholarship Part of the Contracts Commons

\section{Recommended Citation}

Charles L. Knapp, Reliance in the Revised Restatement: The Proliferation of Promissory Estoppel, 81 Colum. L. Rev. 52 (1981). Available at: http://repository.uchastings.edu/faculty_scholarship/344

This Article is brought to you for free and open access by UC Hastings Scholarship Repository. It has been accepted for inclusion in Faculty Scholarship by an authorized administrator of UC Hastings Scholarship Repository. For more information, please contact marcusc@uchastings.edu. 


\section{Faculty Publications \\ UC Hastings College of the Law Library}

Author: Charles L. Knapp

Source: $\quad$ Columbia Law Review

Citation: 81 Colum. L. Rev. 52 (1981).

Title: Reliance in the Revised Restatement: The Proliferation of Promissory Estoppel

Originally published in COLUMBIA LAW REVIEW. This article is reprinted with permission from COLUMBIA LAW REVIEW and Columbia University School of Law. 


\title{
Reliance in the Revised Restatement: The Proliferation of Promissory Estoppel
}

\author{
Charles L. Knapp*
}

The original Restatement of Contracts' stated three requirements for the formation of a contract: a promisor and promisee each with legal capacity, a manifestation of assent, and sufficient consideration. ${ }^{2}$ Following its detailed treatment of these conventional elements of the ordinary contract, ${ }^{3}$ the Restatement presented a group of sections dealing with "Informal Contracts Without Assent or Consideration." " Most of these "informal contracts" involved later promises to perform obligations that originally arose out of transactions in which assent and consideration had played a part, but that (for a variety of reasons) had become unenforceable; thus they did not represent exceptions to the general proposition that promissory liability depends on both mutual assent and an underlying exchange of consideration. In section 90, however, the Restatement did present such a clear-cut exception. In a mere six lines of black-letter text, section 90 called for the enforcement of a different kind of promise: a "Promise Reasonably Inducing Definite and Substantial Action." 6 The original section 90 had no supporting comments; it was followed by four illustrations, of three promises that were enforceable under section $90^{7}$ and one that was not. ${ }^{8}$

* Associate Dean and Professor of Law, New York University. B.A. 1956, Denison; J.D. 1960, New York University.

1. Restatenient of Contracts (1932) [hereinafter citcd as Restatement].

2. Restatement § 19.

3. Restatentent ch. 2, "Formation of Contracts-General Principles," §§ 15, 18; Restatement ch. 3, topic 2, "Manifestation of Assent," $\S \S 20-74$; Restatcment ch. 3, topic 3, "Consideration and Its Sufficiency," $\S \$ 75-84$.

4. Restatement ch. 3, topic 4 , §§ 85-94.

5. Restatenrent $\S 86$ ("Promise to Pay a Debt Barred by the Statute of Linitations"): Restatement $\S 87$ ("Promise to Pay a Debt Discharged in Bankruptcy"); Restatement $\S 88$ ("Promise to Perform a Duty in Spite of Non-performance of a Condition"); Restatement $\$ 89$ ("Promise to Perform a Voidable Duty").

All four sections involvcd promises grounded on earlier agreements that were presumably binding bargained-for exchanges. Section 88 was sonewhat different in that it addressed the question of whether one promisor's manifested willingness to forgo the benefit of a condition to his or her duty should be bindimg despite a later change of heart on that point.

6. Restatenient $\S 90$, "Promise Reasonably Inducing Definite and Substantial Action," provides: A promise which the promisor should reasonably expect to induce action or forbearance of a definite and substantial character on the part of the promisee and which does induce such action or forbearance is binding if injustice can be avoided only by enforcement of the promise."

7. Restatement $\$ 90$ provides the following illustrations:

Illustration 1:

A promises B not to foreclose for a specified time, a mortgage which A holds on B's land. B thereafter makes improvements on the land. A's promise is binding;

Illustration 2:

A promises B to pay him an annuity during B's life. B thereupon resigns a profitable employment, as A expected that he niight. B receives the annuity for some years, in the meantime becoming disqualified from again obtaining good emfloyment. A's promise is binding; 
With hindsight it is evident that putting section 90's action-inducing promise in the company of such modest and familiar notions as the promise to pay a debt discharged in bankruptcy was like putting Pavarotti in a barbershop quartet. Although the Restatement (Second) ${ }^{9}$ reflects some growth in other areas covered by the topic "Contracts without Consideration," 10 the principle of section $90-$ now commonly known as "promissory estoppel" or enforcement grounded on "reliance," although section 90 used neither term-has become perhaps the most radical and expansive development of this century in the law of promissory liability."

It has sometimes been asserted that promissory estoppel serves only as a "substitute for consideration"; ${ }^{12}$ the original section 90 itself, however, contained no such limitation, and the first Restatement indicated that the element of promise-induced action could make up for the absence of a "manifestation of assent" as well as for the lack of consideration. ${ }^{13}$ Moreover, comment $f$ to former section 178 also declared that a "promissory estoppel" (here using the term that section 90 eschewed) could overcome the absence of a signed writing in cases where the Statute of Frauds would otherwise prevent enforcement. In recent years, courts have applied the principle of section 90 to enforce not only purely "donative" promises, but also "gratuitous" promises in a commercial setting; ${ }^{14}$ they have also permitted plaintiffs generally to use the reliance principle to overcome defenses of form, such as the Statute of Frauds. ${ }^{15}$ Some have

\section{Illustration 3:}

A promises B that if B will go to college and complete his course he will give him $\$ 5000$. B goes to college and has nearly completed his course when A notifies him of an intention to revoke the promise. A's promise is binding.

8. Restatement $\$ 90$ illustration 4: "A promises B $\$ 5000$, knowing that B desires that sum for the purchase of Blackacre. Induced thereby, $B$ secures without any payment an option to buy Blackacre. A then tells B that he withdraws his promise. A's promise is not binding."

9. Restatement (Second) of Contracts (1981) [hereinafter cited as Restatement (Second)].

10. For example, a new $\$ 86$ has been added, calling for enforcement in some cases of promises made in recognition of past benefits conferred. The section is bottoned on unjust enrichment, rather than "past consideration" or "moral obligation," and therefore is said to make no change in the outcome of a case like Mills v. Wyman, 20 Mass. (3 Pick.) 207 (1825) (father not liable on promise to pay for care previously furnished to adult son). Restatement (Second) of Contracts $\S 86$ commient a, illustration 1 (1981). Unlike revised $\$ \S 87,88$, and $89, \S 86$ rests on a benefit conferred by the promisee before the making of the promise and has no direct bearing on the general question of protection for unbargained-for relianee. There is, however, a suggestion in comment $b$ to $\$ 86$ that subsequent reliance on the promise "may be relevant to show that no imposition results from enforcement." This seems slightly askew; it might have been more to the point to note that under $\S 90$, reliance on even a donative promise may furnish a reason to enforce, and that reliance on a promise that is founded on moral obligation - and to that extent is not purely "donative"-may be both particularly foreseeable and particularly reasonable.

11. See gencrally Boyer, Promissory Estoppel: Requirements and Limitations of the Doctrine, 98 U. Pa. L. Rev. 459 (1950); Boyer, Promissory Estoppel: Principle from Precedents (pts. I \& II), 50 Mich. L. Rev. 639, 873 (1952); Henderson, Promissory Estoppel and Traditional Contract Doctrine, 78 Yale L.J. 343 (1969).

12. See, e.g., Allegheny College v. National Chautauqua County Bank, 246 N.Y. 369, 373-74, 159 N.E. 173, 175 (1927) (Cardozo, C.J.).

13. Restateinent \& 19(b).

14. See, e.g., Drennan v. Star Paving Co., 51 Cal. 2d 409, 333 P.2d 757 (1958).

15. See, e.g., McIntosh v. Murphy, 52 Hawaii 29, 469 P.2d 177 (1970). 
even declared that the protection of promise-induced reliance is not merely the enforcement of an "informal contract" (the terminology employed in the first Restatement ${ }^{16}$ ) but the imposition of a distinct kind of liability, with its own theory, and perhaps subject to its own legal rules. ${ }^{17}$

Recognizing the widespread acceptance of the principle of section 90 , and faced with its burgeoning applications, the drafters of the Restatement (Second) have attempted, with considerable success, to steer a middle course. On the one hand, they have retained almost without change the language of the original section 90 (even, with some refinement, its original illustrations ${ }^{18}$ ). They have appended substantial comment to the new section 90, however, and added several new illustrations of typical applications of the rule. ${ }^{19}$ At the same time, they have "spun off" a few of the more significant applications of section 90 into new sections of their own. ${ }^{20}$ The discussion below will focus first on section 90 in its new form, then on its principal satellite sections; after that we will briefly note other ways in which the reliance principle influences the Restatement's scheme, and consider what may be the likely path of future developments in this area.

16. See text accompanying notes 4-5 supra.

17. See, e.g., Hoffman v. Red Owl Stores, Inc., 26 Wis. 2d 683, 698, 133 N.W.2d 267, 275 (1965) (" [w]e deem it would be a mistake to regard an action grounded on promissory estoppel as the equivalent of a breach of contract action"); Janke Constr. Co. v. Vulcan Materials Co., 386 F. Supp. 687, 697 (W.D. Wis. 1974) ("the statute of frauds relates to the enforceability of contracts; promissory estoppel relates to promises which have no contractual basis and which are enforced only when necessary to avoid injustice") (emphasis in original). See also Seavcy, Reliance Upon Gratuitous Promises or Other Conduct, 64 Harv. L. Rev. 913, 926-928 (1951).

18. New illustration 2, replacing former illustration 1 , see note 7 supra, defines the nature of $B$ 's remedy (foreclosure will be denied until the time stated has elapsed). The new illustration 4 , replacing illustration 2 , see note 7 supra, has been made more realistic by characterizing $B$ as $A$ 's employer. New illustration 1, replacing illustration 3, see note 7 supra, is now conceded to call for flexible application of conventional consideration analysis. New illustration 15, revising illustration 4, note 8 supra, now addresses an option to purchase "a parcel of land," instead of the now apparently old-hat "Blackacre." Restatement (Second) § 90 illustrations 2, 4, $1 \& 15$, reporter's notes.

19. These include a charitable gift, illustration 17, see text accoinpanying notes 51-58 infra; a promise to give land, relied on by the donee in making valuable improvements thereon, illustration 7; gratuitous promises to procure imsurance, illustrations $13 \& 14$; and promises to grant a "dealer franchise," illustrations $8 \& 9$, see note 24 infra and discussion in text accompanying notes 24-27 infra, and illustration 10, see text accompanying notes 36-41 infra. The device of "illustration"really an attempt to abstract from an actual decided case-has always been somewhat awkward. If the abstraction appears to leave out or distort relevant facts of the real case on which it is based, then it seems a less trustworthy depiction of the common law rule in action, for obvious reasons. See, e.g., the discussion of illustrations 8 and 9 to $\S 90$ at text accompanying notes 24-27 infra. On the other hand, an "illustration" that is no more than an elaborate statement of the detailed facts of a specific case seems of little or no value as an explanation for the prineiple that it purports to "illustrate"; one might as well read, analyze, and cite the decided case itself. See, e.g., Restatement (Seeond) § 90 illustration 10 (substantially a report of the facts and result of Hoffman v. Red Owl Stores, Inc., 26 Wis. 2d 683, 133 N.W.2d 267 (1965)). Sce also text accoinpanying notes 36-41 infra.

20. See Restatement (Second) $\S 87$ ("Option Contract," discussed in text accompanying notes 62-85 infra), 88 ("Guaranty"), 89 ("Modification of Executory Contract," discussed in text accompanying notes 100-18 infra), 139 ("Enforcement by Virtue of Action in Reliance," where the Statute of Frauds is not satisfied, discussed in text accompanying notes 90-98 infra) \& 150 ("Reliance on Oral Modification," discussed in text accompanyimg notes 115-21 infra). 


\section{Enforcement of the Promise That Induces Reliance: Section 90}

Section 90. Promise Reasonably Inducing Action or Forbearance (1) A promise which the promisor should reasonably expect to induce action or forbearance on the part of the promisee or a third person and which does induce such action or forbearance is binding if injustice can be avoided only by enforcement of the promise. The remedy granted for breach may be limited as justice requires.

(2) A charitable subscription or a marriage settlement is binding under Subsection (1) without proof that the promise induced action or forbearance.

\section{A. Limitations on Remedy}

The principal change made in section 90 by the drafters of the Restatement (Second) is the express suggestion to courts that "enforcement" of a promise under the section may not require an award of the full expectation value of the promise; the remedy may instead be "limited as justice requires." This is, of course, a response to numerous writers over the years who have differed with Professor Williston's assertion that a promise enforced under section 90 is a "contract," and therefore must be enforceable, as is any other "contract," to the full extent of the promised expectation." Comment d, "Partial enforcement," elaborates on this change, asserting that although a promise binding under section 90 is indeed "a contract," making "full-scale enforcement . . . often appropriate," the character and extent of the remedy should be considered in the light of "the same factors which bear on whether any relief should be granted." In some cases, relief may be limited to less than the expectation-to restitution, or to relief "measured by the extent of the promisee's reliance." 2

This commentary provides some guidance to courts applying section 90 , and it spares them from having to choose between full enforcement and no enforcement. ${ }^{23}$ Serious questions remain, however: what factors should prompt the court to grant the full expectation, and when should the promisee be limited to a reimbursement for reliance?

The examples furnished by the drafter are few. The first pair of illustrations to comment $\mathrm{d}^{24}$ contrasts a case very much like Goodman v. Dicker ${ }^{25}$ with one

21. See, e.g., Eisenberg, Donative Promises, 47 U. Chi. L. Rev. 1, 21-26 (1979); Fuller \& Perdue, The Reliance Interest in Contract Damages (pt. 2), 46 Yale L.J. 373, $401-06$ (1937).

22. By contrast, unless the promisor would otherwise be unjustly enriched, damages should not exceed the value of the promised performance; thus, it would ordinarily be inproper to grant "consequential damages" in excess of that value, at least in the case of a "promise to make a gift." Restatement (Second) $\$ 90$ comment d.

23. Cf. U.C.C. \& 2-302(1) (contemplating full enforcement of the contract ininus the unconscionable provision, limited application to avoid an unconscionable result, or no enforcement).

24. Those illustrations are as follows:

8. A applies to B, a distributor of radios manufactured by $C$, for a "dealer franchise" to sell C's products. Such franchises are revocable at will. B erroneously informs A that C has accepted the application and will soon award the franchise, that $A$ can proceed to employ salesmen and solicit orders, and that A will receive an mitial delivery of at least 30 
similar on its facts to Chrysler Corp. v. Quimby. ${ }^{26}$ The implication of the contrasted illustrations is that lost profits will be granted or denied on the basis of the promisor's culpability. In fact, the court in the Quimby case distinguished Goodman on the ground that in Quimby the promised dealership was not to be terminable until at least ninety days had elapsed, and therefore the injury suffered by the plaintiff included a loss of ninety days' profit. ${ }^{27}$ The force of these two illustrations is undercut by their failure accurately to reflect the cases on which they are frankly patterned. ${ }^{28}$ Two other illustrations to comment $d$ involve land. In one, the enforcement of a promise not to obstruct the plaintiff's view is limited to the period during which plaintiff and his successors "do not permanently terminate the use of the view"; ${ }^{29}$ such a limitation on remedy was imposed in the case on which the illustration is based, but seems not to have been the focus of concern or discussion by the court. ${ }^{30}$ In the other illustration, a promised gift of land is not enforced "because the proof of the terms of the promise is not sufficiently clear and definite," although the donee is held entitled to a lien on the land for the value of the improvements he made thereon, not exceeding their cost. ${ }^{31}$ This is recognition more of the restitution than of the reliance interest; it therefore sheds little light on the question of when the reliance interest per se is to be the measure of damage. ${ }^{32}$

In its original "tentative" form, the revised Restatement said no more about the issue of remedy limitation. ${ }^{33}$ Except for a suggestion that the remedy for breach of a promise to make a gift should rarely extend to consequential damages greater than the burden of full performance, no distinction was drawn between donative promises and those made "gratuitously" but in a commercial setting. Instead, it was simply suggested that "the same factors which bear on whether any relief should be granted also bear on the character and extent of the remedy." ${ }^{34}$ Since the promulgation of revised section 90 as part of Tentative

radios. A expends $\$ 1,150$ in preparing to do business, but does not receive the franchise or any radios. $\mathrm{B}$ is liable to $\mathrm{A}$ for $\$ 1,150$ but not for the lost profit on 30 radios. Compare Restatement (Second) of Agency $\$ 329$.

9. The facts being otherwise as stated in Illustration $8, \mathrm{~B}$ gives $\mathrm{A}$ the erroneous information deliberately and with C's approval and requires $A$ to buy the assets of a deceased former dealer and thus discharge C's "moral obligation" to the widow. C is liable to A not only for A's expenses but also for the lost profit on 30 radios.

Restatement (Second) $\$ 90$ comment d, illustrations $8 \& 9$.

25. 169 F.2d 684 (D.C. Cir. 1948).

26. 51 Del. 264, 144 A.2d 123 (1958).

27. Id. at 283,144 A.2d at 134 .

28. See Restatement (Second) $\$ 90$ comment d, reporter's note.

29. Restatement (Second) $\$ 90$ illustration 11.

30. Miller v. Lawlor, 245 Iowa 1144, 1150, 66 N.W.2d 267, 271 (1954).

31. Restatement (Second) $\S 90$ illustration 12.

32. The revised Restatement explicitly defines the "reliance interest," § 344(b), and states that it inay be einployed as a measure of damages where the value of the plaintiff's expectation is uncertain. Restatement (Second) $§ 349$ comment a. It offers no guidance, however, on the proper measure to be employed in cases imvolving $\S 90$ or other applications of promissory estoppel. Id., comment $b$.

33. Restatement (Second), Contracts $\S 90$ (Tent. Draft No. 2, April 30, 1965).

34. Id., comment e. This language was carried forward, without change, in what is now cominent $d$ of the final version. 
Draft No. 2, some decisions ${ }^{35}$ have followed the drafters' suggestion that damages be limited to compensation of the reliance interest. One of these, Hoffman v. Red Owl Stores, Inc. ${ }^{36}$ has been used as the model for a new illustration to the final version of revised section 90:

10. A, who owns and operates a bakery, desires to go into the grocery business. He approaches B, a franchisor of supermarkets. B states to A that for $\$ 18,000 \mathrm{~B}$ will establish $\mathrm{A}$ in a store. B also advises $\mathrm{A}$ to move to another town and buy a small grocery to gain experience. A does so. Later B advises A to sell the grocery, which A does, taking a capital loss and foregoing expected profits from the summer tourist trade. B also advises A to sell his bakery to raise capital for the supermarket franchise, saying "Everything is ready to go. Get your money together and we are set." A sells the bakery, taking a capital loss on this sale as well. Still later, B tells A that considerably more than an $\$ 18,000$ investment will be needed, and the negotiations between the parties collapse. At the point of collapse many details of the proposed agreement between the parties are unresolved. The assurances from $B$ to $A$ are promises on which $B$ reasonably should have expected $A$ to rely, and A is entitled to his actual losses on the sales of the bakery and grocery and for his moving and temporary living expenses. Since the proposed agreement was never made, however, $\mathrm{A}$ is not entitled to lost profits from the sale of the grocery or to his expectation interest in the proposed franchise from $B .{ }^{37}$

As a student's brief of the facts of the Hoffman case, illustration 10 seems accurate enough; as an elaboration of the limitation-on-remedy principle, it is somewhat Delphic. If the proposed franchise agreement between " $A$ " (Hoffman) and " $B$ " (Red Owl) had been entered imto, then upon its subsequent breach, Hoffman might have claimed expectation damages, including lost profits; any such recovery would have been subject, however, to principles of foreseeability, certainty, and causation, one or more of which might well have denied him any remedy beyond out-of-pocket expenses. ${ }^{38}$ However, the drafters of illustration 10 limit $A$ 's remedy not for any of those reasons, but because "the proposed

35. Besides Hoffman v. Red Owl Stores, Inc., 26 Wis. 2d 683, 133 N.W.2d 267 (1965), discussed in the text immediately following note 36 , see Wheeler v. White, 398 S.W.2d 93 (Tex. 1965). The reporter's note to revised $\S 90 \mathrm{~m}$ its final version also cites as support for Hoffman a construction bid case, Janke Constr. Co. v. Vulcan Materials Co., 386 F. Supp. 687 (W.D. Wis. 1974), aff'd, 527 F.2d 772 (7th Cir. 1976). However, although both courts deciding the Janke case referred to "reliance damages," the District Court awarded, and the Court of Appeals upheld, damages based on the difference between the price offered by defendant and the price at which plaintiff was able to procure a substitute-in other words, the classic expectation remedy, as limited by the mitigation principle. See 386 F. Supp. at $695,698,527$ F.2d at 780 . This is the usual remedy in such cases even where promissory estoppel is the basis of enforcement. See, e.g., Saliba-Kringlen Corp. v. Allen Eng'r Co., 15 Cal. App. 3d 95, 92 Cal. Rptr. 799 (1971) (modifying a lower-court award of less than full expectation remedy). See also Note, Once More into the Breach: Promissory Estoppel and Traditional Damage Doctrine, 37 U. Chi. L. Rev. 559, 571 (1970).

36. 26 Wis. 2d 683, 133 N.W.2d 267 (1965).

37. Restatement (Second) $\$ 90$ comment d, illustration 10.

38. Sce generally Dobbs, Remedies $\$ 12.3$ (1973). 
agreement was never made." Do they mean to say that whenever the parties have failed to conclude a conventional "contract" the disappointed party should be limited to reliance damages? If so, this seems to be not a flexible rule limiting recovery "as justice requires," but a per se rule, since ordinarily a case will be decided under section 90 only when it involves either a donative promise that is not part of any "contract" at all, or a promise that, although made in a commercial setting and involving an actual or potential exchange, is itself not part of an enforceable, consideration-supported "contract." ${ }^{39}$ If the drafters really mean that "justice" never "requires" compensation beyond the reliance interest when promissory estoppel alone is the basis for the enforcement, they should have said so in section 90 . Not all of us would agree, but at least there would be clarity..$^{40}$ On the other hand, if they meant that a full expectation remedy is sometimes appropriate in such cases, then illustration 10 fails to guide the courts in deciding any case other than one that tracks the facts of Hoffman to an improbable degree. The drafters may succeed in freeing the courts from fullenforcement-or-none dilemma by which some may have felt themselves confronted. However, if this revision in section 90 creates an impression that the remedy for promise-based reliance should always be limited to the value of that reliance, then both the flexibility of section 90 and its capacity to remedy injustice may be diminished. ${ }^{41}$

\section{B. The Character of Reliance}

One byproduct of section 90 's new reference to limitation on remedy is the deletion of the portion of the original version that required the action induced by the promise to be "of a definite and substantial character." This deletion responds to the argument of Fuller and Perdue that the section as originally drafted appeared to require the promisee's reliance to have been "definite and substantial" enough to justify full enforcement of the expectation created by the promise; ${ }^{42}$ the drafters seem to have assumed that retention of that language would undercut the new policy of permitting partial enforcement. ${ }^{43}$ That may be, but the point is certainly open to question. Do the drafters really mean to

39. Such a per se rule seems to have been endorsed hy the Texas Supreme Court in Wheeler v. White, 398 S.W.2d 93, 97 (Tex. 1965) ("[w] there the promisee has failed to bind the promisor to a legally sufficient contraet, hut ... has acted in reliance upon a promise to his detriment, the promisee is to be allowed to recover no more than reliance damages measured by the detriment sustained").

40. Of course, clarity of principle does not always bring certainty of application; it still may be difficult in a given case to calculate the true cost to plaintiff of defendant's breach of promise. For example, one commentator questions the correctness of the court's computation of the injury to Hoffman caused by Red Owl's failure to award him the promised grocery franchise. See Comment, 65 Mieh. L. Rev. 351 (1966).

41. A persuasive case for the notion that full expectation remedies are ordinarily appropriate whenever promissory estoppel is invoked to enforce promises made in a commercial setting (if only to protect fully all types of likely reliance, including forbearance to seek the next-best alternative) can be found in Note, Onee More into the Breach: Promissory Estoppel and Traditional Contract Doctrine, note 35 supra.

42. Fuller \& Perdue, supra note 21 , at 402.

43. See Restatement (Second) $\$ 90$ reporter's note. 
suggest that a promisee whose reliance was both "indefinite" and "insubstantial" should nevertheless be entitled to a remedy? Section 90's new comment b refers to the "definite and substantial character [of the promisee's reliance] in relation to the remedy sought" as one of the factors to consider in applying section 90, and the same point is made in the text of new section 139(2)(b), which applies promissory estoppel to the Statute of Frauds. ${ }^{44}$ The satellite promissory estoppel sections all retain a "substantiality" test or its equivalent. ${ }^{45}$ The deletion of that requirement from the text of section 90 itself not only creates some potentially confusing "legislative history," but it may also inaccurately reflect the attitude of the courts in these cases. Promissory estoppel is currently employed where the promise sought to be enforced is not supported by any currently-exchanged consideration, ${ }^{46}$ is somehow indefinite or incomplete, ${ }^{47}$ or is made with insufficient formality. ${ }^{48}$ In the light of the important policies underlying consideration and form, ${ }^{49}$ a court might well require in all three of those situations that the plaintiff seeking enforcement demonstrate reliance that is both definite and substantial. Of course, in the circumstances of a particular case even substantial reliance may appear to call for only partial enforcement of the promise; thus, insubstantial reliance might merit no remedy at all. ${ }^{50}$

The drafters expressly indicate, however, that some cases warrant full enforcement of the promised performance, whatever the degree of reliance on the part of the promisee. Subsection 90(2) provides that a charitable subscription or a marriage settlement promise should be binding "under Subsection (1)" even if there is no showing that action or forbearance was induced thereby. ${ }^{51}$ Comment $\mathrm{f}$ to section 90 , devoted to "charitable subscriptions, marriage settlements and other gifts," observes that enforcement of a gift promise will ordinarily be forthcoming only in cases where the promisee's reliance is "foreseeable and reasonable," involving "a definite and substantial change of position." However, in cases of marriage settlements and charitable subscriptions, it is asserted that

44. This new section is quoted and discussed at text accompanying notes $90-98$ infra.

45. Restatement (Second) §§ 87(2), 88(c), 89(c) \& 150.

46. This is the function of reliance in Restatement (Second) $\S \S 87(2), 88(\mathrm{c}), 89$ (c) \& 90 .

47. E.g., Wheeler v. White, 398 S.W.2d 93 (Tex. 1965); see Restatement (Second) § 34(3); id. comment d.

48. See text accompanying notes 90-98 \& 115-21 infra (discussing Restatement (Second) $\S \S$ 139, 150).

49. The classic exposition of the "evidentiary," "cautionary," and "channeling" functions of formality is Fuller, Consideration and Form, 41 Colum. L. Rev. 799, 800-804 (1941).

50. See Boyer, Promissory Estoppel: Requirements and Limitations of the Doctrine, $98 \mathrm{U}$. Pa. L. Rev. 459, 475-480 (1950). But see Eisenberg, note 21 supra, at 21-22. Deletion of the "definite and substantial" test from the text of $\S 90$ may have been a concession to the suggestion, originally made only in a comment, that enforcement might well be appropriate in charitable-suhscription cases despite plaintiff's failure to establish substantial acts of reliance. See Restatement (Second) of Contracts $\S 90$ comment $\mathrm{c}$ (Tent. Draft No. 2, April 30, 1965). Now that charitable cases are dealt with separately in a new subsection (2) to $\S 90$, there is even less reason to suggest that in ordinary cases under $\$ 90$ the court should be indifferent to the definite or substantial character of the plaintiff's action in reliance.

51. Originally the principle expressed in $\S 90(2)$ was not stated in revised $\S 90$ itself, but only in comment $c$ thereto. Restatement (Second) $\S 90$, comment $c$ (Tent. Draft No. 2, April 30, 1965). In the final version of the revised Restatement, that comment (redesignated " $f$ ") is retained without substantial change, hut the principle it advances has also been incorporated into the text of $\S 90$. 
American courts have traditionally favored enforcement; thus a mere "probability of reliance" is apt to be sufficient to justify enforcement, with no effort by the court either to "sort out mixed motives" or "to consider whether [only] partial enforcement would be appropriate."

Marriage settlements may be uncommon today, but charitable subscriptions aggregating vast sums are made every year, and their potential enforceability is important to many. Here, then, the drafters have come down squarely on the side of enforceability, but without significantly clarifying the legal issues involved. Enforcement of charitable pledges has been justified sometimes by consideration, ${ }^{32}$ sometimes by assertions of reliance on the donee's part, ${ }^{33}$ and sometimes by virtually naked assertions of public policy. ${ }^{54}$ Of these three rationales, only the last seems both legally and practically sufficient to ensure enforcement in nearly all cases. Where consideration is deemed present, it may be found either in the mutual promises of all donors, or in some act or condition imposed by the promisor as the "price" of the gift. In many cases, however, this theoretical basis for enforcement appears to be no more than a convenient legal fiction.s On the other hand, not every prospective charitable donee can demonstrate foreseeable and detrimental reliance upon a particular promise so that its enforcement is justified on that basis. ${ }^{56}$ Thus, many charitable donative promises would go unenforced if their enforcement depended on passing either a consideration test or a reliance test, stringently applied.

To maximize the enforceability of charitable subscriptions, the Restatement proposes what is essentially a fictional test of reliance-the mere "probability" of reliance will suffice, and no proof of actual action or forbearance will be demanded as a predicate to enforcement. This approach has the effect of somewhat distorting the emphasis of section 90; the "injustice" of nonenforcement in such cases is really to be found not in a change of position by the promisee but in the asserted social utility of enforcement. ${ }^{57}$ A somewhat more satisfying statement of the reliance-based policy of section 90 with regard to charity cases might resemble the following: our society depends on private charity to carry on many necessary activities that would otherwise have to be performed by the

52. See, e.g., Congregation B'nai Sholom v. Martin, 382 Mich. 659, 173 N.W.2d 504 (1969) (reversed to permit defendant to interpose a defense based on asserted principle of religious law).

53. See, e.g., Estate of Timko v. Oral Roberts Evangelistic Ass'n, 51 Mich. App. 662, 215 N.W.2d 750 (1974).

54. See, e.g., Woodmere Acad. v. Steinberg, 41 N.Y.2d 746, 363 N.E.2d 1169 (1977), noted at 97 A.L.R.3d 1047 (1977); Annot., 97 A.L.R.3d 1054 (1977).

55. See J. Calamari \& J. Perillo, Contracts § 6-5 (2d ed. 1977).

56. See Jordan v. Mount Sinai Hosp. of Greater Miami, Inc., 276 So. $2 d 102$ (Fla. Dist. Ct. App. 1973), aff'd, 290 So. 2d 484 (1974) (finding neither consideration nor reliance; denying recovery on a written promise of contribution).

57. The reporter's note to comment $f$ observes that some authorities have approvingly interpreted $\S 90(2)$ as treating charitable subscriptions as "a sui generis category requiring neither consideration nor reliance." The implication is that the drafters also accept this description of $\S 90(2)$, despite the fact that the subsection refers to the promise affected thereby as being "binding under Subsection (1)"-i.e., under the general principle of $\S 90$ itself. If a charitable-subscription nule is to be frankly rested on public policy, it seens questionable whether this rule should be set in the context of $\S 90$. 
government or not at all; charitable organizations rely from year to year on the likely performance in the aggregate of the promises of support they receive, and incur substantial contractual and other obligations in reliance on those promises; therefore, the law should enforce all such promises, despite the difficulty of showing that any particular promise produced substantial reliance, or of arguing that injustice would result if that promise alone were to go unperformed.

Subsection 90(2) and comment $f$ together suggest that enforcement of charitable-donation promises should be easy to obtain in most cases. At the same time, the fiction of reliance suggests that charitable promises should be cautiously enforced. In the case of a charitable subscription where it is not possible to show reliance on the particular promise to any substantial degree, it may be entirely appropriate for a court to place somewhat greater weight on other factors specified in comment b to section 90 , such as "the formality with which the promise is made" and "the extent to which the evidentiary, cautionary, deterrent and channelling functions of form are met." ${ }_{58}$ This might be achieved by insisting on either a writing or other credible evidence to show the genuineness and the deliberateness of the promise in question.

\section{Reliance by a Third Party}

The other principal change in the text of section 90 is the express reference to reliance by a third party as possibly deserving a remedy. Here the text refers not only to third parties who are the intended beneficiaries of a promised performance, but also to others who may foreseeably rely on a promised performance in making expenditures or taking other action of their own. ${ }^{59}$ The decisions seem to support the general proposition that enforcement is proper in such cases, provided the elements of foreseeability and potential injustice are present. ${ }^{60}$

58. If this suggestion is sound, it is unfortunate that the drafters of revised $\S 90$ have provided only the following illustration of a charitable gift promise:

17. A orally promises to pay $B$, a university, $\$ 100,000$ in five annual installments for the purposes of its fund-raising campaign then in progress. The promise is confirmed in writing by A's agent, and two annual installments are paid before $A$ dies. The continuance of the fund-raising campaign by $B$ is sufficient reliance to make the promise binding on $A$ and his estate.

Restatement (Second) $\S 90$ comment f, illustration 17. Presumably, A's initial promise is described as oral in order to track more closely the facts of In re Field, 11 Misc. $2 d$ 427, 172 N.Y.S.2d 740 (Sur. Ct. 1958). See Restatement (Second) $\$ 90$ comment f, reporter's note. In that case, however, the "agent" was the promisor's son and residuary legatee, Marshall Field, Jr., who apparently stood ready himself to make good on his father's pledges if necessary. Despite the adversarial setting, one suspects that all parties to the suit wanted the decedent's promises to be held legally binding on his estate.

59. See Restatement (Second) $\$ 90$ comment c. Query whether this is entirely consistent with Restatement (Second) $\S 302$ comment d, which suggests the following as one test for identifying an "intended" third-party beneficiary (i.e., one who can legally enforce the duty created by the contract to which he or she is not a party): "[I]f the beneficiary would be reasonable in relying on the promise as inanifesting an intention to confer a right on him, he is an intended beneficiary."

60. In addition to the cases cited in Restatement (Second) $\$ 90$ comment $c$, reporter's note, support may be found in Aronowicz v. Nalley's, Inc., 30 Cal. App. 3d 27, 106 Cal. Rptr. 424 (1972), and Hoffman v. Red Owl Stores, Inc., 26 Wis. 2d 683, 133 N.W. 2d 267 (1965); cf. C.R. Fedrick, Inc. v. Sterling-Salem Corp., S07 F.2d 319, 322 n.9 (9th Cir. 1974) (plaintiff contractor 


\section{Reliance on an Unaccepted Offer: Section 87}

\section{A. Reliance on an Option Contract}

In the folklore of law teaching, few things gave professors of an earlier day as much pleasure as demonstrating to confused students the inherent revocability of an ordinary offer, even if that offer by its own terms purported to be irrevocable, and even if - as in the familiar example of an offer for a unilateral contract - the offeree was halfway across the Brooklyn Bridge. Section 45 of the first Restatement of Contracts did a good deal to dispel some of that foolishness; ${ }^{61}$ Restatement (Second) attempts to deliver a death blow to the unilateral contract in its harsh, traditional form. ${ }^{62}$ The Restatement (Second) also demonstrates, in the new section 87, that strict law of offer and acceptance has been stood on its head by more recent developments, both legislative and judicial. That section, new in this Restatement, provides as follows:

\section{Section 87. OPTION CONTRACT.}

(1) An offer is binding as an option contract if it

(a) is in writing and signed by the offeror, recites a purported consideration for the making of the offer, and proposes an exchange on fair terms within a reasonable time; or

(b) is made irrevocable by statute.

(2) An offer which the offeror should reasonably expect to induce action or forbearance of a substantial character on the part of the offeree before acceptance and which does induce such action or forbearance is binding as an option contract to the extent necessary to avoid injustice.

Section 87 does not refer to the possibility that an offer may be irrevocable because it has been "paid for" with consideration of the ordinary kind; that possibility is dealt with elsewhere. ${ }^{63}$ Rather, section 87 addresses the possibility

denied recovery on reliance theory where defendant's price quoted to plaintiff's supplier, upon which plaintiff claimed to have relied, differed substantially from supplier's price quoted to plaintiff; court suggests that reliance protection should be accorded only to third party "in complete privity with the terms of the promise made by the promisor'). See also Silberman v. Roethe, 64 Wis. 2d 131, 218 N.W.2d 723 (1974).

61. Section 45 of the first Restatement provided that the offeror could not revoke an offer for a unilateral contract once the requested act (serving as both consideration and acceptance) had been partially performed. The substance of $\S 45$ has been retained in the revision, considerably fleshed out with new comments and illustrations. Restatement (Second) $\$ 45$ comment f notes (as did Restatement $\S 45$ comment a) that preparations for performance will not trigger the rule of $\S 45$; they may, however, enable the offeree to employ the principle of $\S 87$.

62. See Restatement (Second), former $\S 12$, reporter's note (Tent. Draft No. 1, 1964) (explaining decision not to employ bilateral/unilateral distinction in Restatement (Second)). There will of course continue to be some offers that can be accepted only by performance, as the drafters concede; the value of their new approach is to remind us that these are few in number, and specific in nature. In most cases, as both Restatement (Second) § 32 and U.C.C. § 2-206 agree, an offer may be accepted by either performance or a promise to perform.

63. Restatement (Second) $\$ 25$ defines "option contract" to include an offer irrevociable because under seal or given for consideration. 
that an offer that has not been so purchased may nevertheless be in legal contemplation irrevocable. Thus, the offer may be deemed legally available for acceptance despite a purported revocation; or some degree of compensation may be provided for the offeree who is disappointed by a revocation that intervenes before he can communicate his intended acceptance.

The section is tidily drafted, its two halves addressing the two possibilities: irrevocability based on form, and enforcement based on substance (reliance). Subsection $87(1)$ describes two types of formality that may make an offer irrevocable. The first of these is the mere written recital of consideration, which purportedly produces irrevocability provided the ultimate exchange contemplated by the offer is itself to be made on fair terms and within a reasonable time. ${ }^{64}$ The other is formal compliance with an applicable statute. The most obvious reference here-although not the only one ${ }^{65}$ - is to the Uniform Commercial Code's "firm offer" provision (section 2-205), which makes an offer to buy or sell goods irrevocable for up to three months, provided it is made by a merchant in a signed writing and purports to be "firm." 66

Subsection 87(2) adopts the position of Justice Traynor, stated in his wellknown opinion in Drennan v. Star Paving Co., ${ }^{67}$ that an offeror may sometimes reasonably rely on the offer before accepting it, and that it may be appropriate in such cases to hold the offer available for acceptance despite an attempted revocation-i.e., that the offer is "binding as an option contract," at least "to the extent necessary to avoid injustice." ${ }_{68}$ This application of promissory estoppel had earlier been considered and rejected by Judge Learned Hand in James Baird Co. v. Gimbel Bros. ${ }^{69}$ In Judge Hand's view, promissory estoppel has no place in the commercial offer-and-acceptance process: businesses understand that an offer confers no legal protection until accepted; moreover, they know how to create a binding option contract if they intend to act in reliance on the offer. ${ }^{70}$ Judge Traynor's rejoinder in Drennan simply emphasized the factors of that case that made preacceptance reliance by the offeree appear both necessary and bene-

64. The revised Restatement, in a reversal, generally rejects the notion of "nominal consideration" as effective to give rise to legal enforceability. Compare Restatement $\$ 84$ comment b \& illustration 1, with Restatement (Second) $\$ 71$ comment b \& illustration 5. However, a mere written recital of consideration-even a false recital, where the described "consideration" did not in fact change hands - is said to be effective to bind an offeror under Restatement (Second) $\& 87(1)(a)$ comments b \& $\mathrm{c}$.

65. Restatement (Second) $\S 87$ comment d refers also to U.C.C. $\S 2-328(3)$ (sale by auction "without reserve") and statutes regulating bidding on government contracts.

66. U.C.C. \& $2-205$ provides in full:

An offer by a merchant to buy or sell goods in a signed writing which by its terms gives assurance that it will be held open is not revocable, for lack of consideration, during the time stated or if no time is stated for a reasonable time, but in no event may such period of irrevocability exceed three months; but any such term of assurance on a form supplied by the offeree must be separately signed by the offeror.

67. 51 Cal. 2d 409, 333 P.2d 757 (1958) (en banc).

68. Restatement (Second) $\S 87(2)$.

69. 64 F.2d 344 (2d Cir: 1933).

70. "The contractors had a ready escape from their difficulty by insisting upon a contract before they used the figures; and in commereial transactions it does not in the end promote justice to seek strained interpretations in aid of those who do not protect themselves." Id. at 346. 
ficial to both parties. ${ }^{71}$ The Traynor view has carried the day; indeed, the reporter's note in support of section $87(2)$ seems remarkably restrained in view of the abundance of authority for this application of the reliance principle. ${ }^{22}$

Since there are several different rules of form and substance that can affect the revocability of an offer, the drafters of the revised Restatement were wise to devote a separate section to this subject. Given the well-developed body of case law underlying section 87(2), however, a somewhat fuller exploration of the problems might have been attempted. For instance, cases following Drennan have rather carefully noted various elements that may determine whether promissory estoppel should protect a disappointed offeree in a given case. ${ }^{33}$ Some general factors are listed in comment e to section 87 , but others discussed in the construction-bidding cases are not, for example whether the offeree acted with reasonable promptness to accept the offer, ${ }^{74}$ whether it engaged in a "bidshopping" process before doing so,$^{75}$ and whether it should have been aware that the offeror had mistakenly underbid. ${ }^{76}$

\section{Judge Traynor stated:}

Though defendant did not bargain for this use of its bid neither did defendant make it idly, indifferent to whether it would be used or not. . . . It was bound to realize the substantial possibility that its bid would be lowest, and that it would be included by plaintiff in his bid. . . Defendant had reason not only to expect plaintiff to rcly on its bid but to want him to. Clearly defendant had a stake in plaintiff's reliance on its bid. Given this interest and the fact that plaintiff is bound by his own bid, it is only fair that plaintiff should have at least an opportunity to accept defendant's bid after the general contract has been awarded to him.

Drennan v. Star Paving Co., 51 Cal. 2d 409, 415, 333 P.2d 757, 760 (1958).

72. Illustration 6 to comment $\mathrm{e}$, dealing with the general contractor's reliance on an unaccepted subcontractor's "bid," was originally supported by citations to only two cases, Drennan and Northwestern Eng'r Co. v. Ellerman, 69 S.D. 397, 10 N.W.2d 879 (1943). Restatcment (Second) \& 89B comment e, reporter's note (Tent. Draft No. 2, April 30, 1965). The final version of the reporter's note cites one additional case in support, W.M. Hcroman \& Co. v. Saia Elec., Inc., 346 So. 2d 827 (La. Ct. App. 1977). The citation is rather mysterious, since its result is grounded not on the $\$ 90$ principle but on a section of the Louisiana Civil Code. See also E.A. Coronis Assoc. v. M. Gordon Constr. Co., 90 N.J. Super. 69, 77-78, 216 A.2d 246, 251 (1966).

73. See, e.g., Saliba-Kringlen Corp. v. Allen Eng'r Co., 15 Cal. App. 3d 95, 92 Cal. Rptr. 799 (1971).

74. Id. (yes); Cayuga Constr. Corp. v. Vanco Eng'r Co., 423 F. Supp. 1182 (W.D. Pa. 1976) (no). Restatement (Second) $\$ 87$ illustration 6 suggests that, once relied on, the offer is irrevocable only until the offeree has had a reasonable opportunity to acccpt.

75. Constructors Supply Co. v. Bostrom Sheet Metal Works, Inc., 291 Minn. 113, 190 N.W.2d 71 (1971). But see Southern Cal. Acoustics Co. v. C.V. Holder, Inc., 71 Cal. 2d 719, 456 P.2d 975, 79 Cal. Rptr. 319 (1969) (en banc).

76. E.g., S.N. Nielsen Co. v. Nat'l Heat \& Power Co., 32 Ill. App. 3d 941, 337 N.E.2d 387 (1975) (yes); Constructors Supply Co. v. Bostrom Sheet Metal Works, Inc., 291 Minn. 113, 190 N.W.2d 71 (1971) (no). The issue of mistake was present in both Drennan, 51 Cal. 2d 409, 333 P.2d 757 (1958), and Baird, 64 F.2d 344 (2d Cir. 1933).

The related question of whether the offeree may in some cases be held to have accepted the offer by virtue of its action in reliance thereon is also ignored in $\$ 87$, exccpt in the reporter's note. See generally Note, Once Around the Flag Pole: Construction Bidding and Contracts at Formation, 39 N.Y.U. L. Rev. 816 (1964); Note, Construction Contracts-the Problem of Offer and Acccptance in the General Contractor-Subcontractor Relationship, 37 U. Cin. L. Rev. 798 (1968); Note, Another Look at Construction Bidding and Contracts at Formation, 53 Va. L. Rev. 1720 (1967). There is some authority for finding a mutually binding contract based on the general contractor's use of the subcontractor's bid. See, e.g., Industrial-Electric-Seattle, Inc. v. Bosko, 67 Wash. 2d 783, 410 P.2d 10 (1966); cf. Southern Cal. Acoustics Co. v. C.V. Holder, Inc., 71 Cal.2d 719, 456 P.2d 975, 79 Cal. Rptr. 319 (1969) (en banc) (California anti-bid-shopping statute held to give disappointed subcontractor cause of action against the gcneral contractor). 
B. Section 87(2) and U.C.C. Section 2-205

Another interesting and potentially important question has been somewhat neglected in the case law; and it is not, then, surprising that the drafters of section 87 failed to address it: the interrelation between the statutory "firm offer" rule of U.C.C. section 2-205 and the reliance-based estoppel provided for in Restatement (Second) section 87(2). ${ }^{7}$ In important ways, these two rules appear not to be congruent. Section 2-205, which requires a "signed writing," does not require the offeree to make any showing of reliance; the effect of that statute is to make the offer literally irrevocable for some period during which it can be "accepted," and the full contract as offered thereby called into effect. By contrast, under section 87(2), an offer that is binding on a promissory estoppel theory need not be signed or made in writing, and the offeree may be protected only to the extent necessary to compensate it for injury to the restitution or reliance interests. ${ }^{78}$ Is there any overlap between these two rules of law? Could a given case invoke both?

First, the disparity in policy is more apparent than real. Section 2-205 of the U.C.C. recognizes that persons in business regard "firm" offers in writing as binding by the standards of good business ethics; such offers therefore give the offeree a reasonable basis for reliance. That reliance unay take many forms: perhaps the offeree has made other ancillary contracts for goods or services; in the case of an offer to sell, the offeree may have committed itself to resell the goods at a stated price. If the offeree's reliance takes either or both of these forms, the policy of promissory estoppel as expressed in section 87(2) could also protect the offeree against an untinely revocation. However, there is one other, less tangible, form of reliance on a firm offer that is likely to occur in inany cases: for a variety of possible reasons, ranging from shrewdness to inefficiency, the offeree may delay in accepting an offer, in the belief that the offer will remain available for the time period specified. ${ }^{79}$ This reliance through inaction is so common, and its proof so subjective-how can the ordinary offeree convincingly demonstrate that it would more promptly have accepted a nonfirm offer-that the drafters of U.C.C. section 2-205 seem amply justified in making their rule a blanket one, with no requirement that actual reliance be proved.

Thus when the offeree in a sale of goods relies on the firmness of an offer, in a tangible and substantial manner, either U.C.C. section 2-205 or Restatement (Second) section $87(2)$ could in theory be used to justify enforcement of the

77. In E.A. Coronis Assoc. v. M. Gordon Constr. Co., 90 N.J. Super. 69, 216 A.2d 246 (1966), the court held that the subcontractor's written offer was not "firm"; it also declined to decide whether the offer was for the sale of goods (governed by Article 2 of the U.C.C.) or of services (outside the Code). It held, however, that the offeree might invoke the doctrine of promissory estoppel, based on an oral offer previously made. The court expressly refrained from considering "whether the existence of section 2-205 of the Uniform Commercial Code precludes reliance on an offer not conforming to its provisions." Id. at $80 \&$ n.2, 216 A.2d at 253 \& n.2.

78. In the construction-bid cases, however, full expectation recovery is the norm. See note 35 supra.

79. The offeree may always have intended to accept eventually; or, it niay have postponed deciding whether or not to accept, in reliance on the offeror's assurance that the offer would remain open. 
obligation not to revoke that offer. Since U.C.C. section 2-205 does not require proof of actual reliance, the offeree's burden under that section would presumably be lighter, but there seems to be no fundamental problem with applying either rule to the same situation. There are, however, situations where both rules appear to be relevant but may lead to different outcomes. Suppose a "firm offer" to sell goods is made, and is relied on, but (a) is not in writing and signed, or (b) is made by a nonmerchant, or (c) purports to be "firm" for longer than three months. Can the offeree, disappointed by an unanticipated revocation but unable to find protection in U.C.C. section 2-205, invoke the principle of Restatement (Second) section 87(2)?

The answer appears to me to be yes, although the issues in each case are somewhat different. As to (a), Drennan itself dealt with an unwritten offer, ${ }^{80}$ and other promissory estoppel decisions suggest that one may reasonably rely in such a case. ${ }^{81}$ As to (b), although the drafters of the U.C.C. have decided that reliance on a merchant's firm offer is per se reasonable, they have not even by implication characterized reliance on a nonmerchant's firm offer as per se unreasonable; the rule of section $87(2)$ therefore seems to be available if the facts of the particular case warrant its use. ${ }^{82}$

The most difficult case is probably (c), where the "firm offer" exceeds the statutory time period. Suppose a merchant makes a firm offer to sell goods, in a signed writing, but it purports to be firm for longer than three months. ${ }^{83}$ Can the offeree who fails to accept until more than three months have elapsedthereby losing the Code's protection-still fall back on Restatement (Second) section 87(2)? The answer should be yes, if the requirements of that section can be met. Although U.C.C. section 2-205 states that "in no event" may the

80. Drennan v. Star Paving Co., 51 Cal. 2d 409, 333 P.2d 757 (1958).

81. See, e.g., E.A. Coronis Assoc. v. M. Gordon Constr. Co., 90 N.J. Super. 69, 216 A.2d 246 (1966).

U.C.C. § 2-205 comment 2 appears to suggest that such reliance would not be reasonable: "[D]espite settled courses of dealing or usages of the trade whereby firm offers are made by oral communication and relied upon without more evidence, such offers remain revocable under this Article since authentication by a writing is the essence of this section." This language can be read, however, as only emphasizing the necessity for a signed writing if the offeree intends to base his cause of action on \$ 2-205; in the light of U.C.C. § 1-103 ("Supplementary General Principles of Law Available," including "estoppel"), it is unnecessary to read U.C.C. \& 2-205 as negating an appropriate result in favor of the offeree under Restatement $\$ 87(2)$. In such a case, the offcr may remain "revocable under this Article," U.C.C. \& 2-205 comment 2 (emphasis supplied), while being irrevocable under another appropriate rule of law.

Of course, the Statute of Frauds may also bar enforcement of an oral offer; not every court will permit the plaintiff-offeree to overcome that rule by a showing of reliance. See, e.g., Tiffany Inc. $v$. W.M.K. Transit Mix, Inc., 16 Ariz. App. 415, 493 P.2d 1220 (1972). See text accompanying notes $86-98$ infra.

82. This might enable a plaintiff-offeree to bypass the troublesome question of the offeror's "merchant" status under U.C.C. \& 2-104(1). See, e.g., Nelson v. Union Equity Co-op. Exch., 548 S.W.2d 352 (Tex. 1977) (wheat farmer held to be a "merchant" for purpose of applying U.C.C. $\S$ 2-201; four justices dissenting).

83. Although it might be argued that the three-month limit in U.C.C. $\$ 2-205$ rcfers only to offers that are "firm" for an indefinite period, it seems clear that the drafters intended to limit promises for a definite period as well. See U.C.C. \& 2-205 comment 3 ("A promise made for a longer period will operate under this section to bind the offeror only for the first three months of the period."). 
period of irrevocability created by such an offer extend beyond three months, comment 3 to that section specifically recognizes the possibility that consideration may bind the offeror for a longer period. ${ }^{84}$ There seems no reason not to extend that principle to the "substitute for consideration" provided by reliancebased estoppel. Thus, the only hurdle for the offeree in such a case is one of proof. It must prove that it acted reasonably when it delayed its acceptance for more than three months while at the same time relying substantially on the offer. If the offer itself specified a period longer than three inonths, such reliance might well seein reasonable, and the requirements of section 2-205 should be irrelevant to the outcome. ${ }^{85}$

\section{Reliance on a Contract Wrthin the Statute of Frauds: Section 139}

American Statutes of Frauds, following their earlier English model, have always provided that certain contracts will not be enforced unless memorialized in a writing and signed by the party to be charged; nevertheless, the courts have also consistently held that reliance-both in the form of performance and in the form of other actions that would not have been undertaken but for the oral agreenent-sometimes furnishes a sufficient basis for relief to a party that has been disappointed by the other's refusal to perform. These principles were reflected in the first Restatement of Contracts ${ }^{86}$ and have been carried forward into the new version. ${ }^{87}$ They rest, however, not so much on reliance as on the principle that where reliance by the promisee would otherwise unjustly enrich the promisor, the promisee should be compensated. ${ }^{88}$

The drafters of the first Restatement suggested a second kind of rule protecting reliance by one party to an oral agreement. Comment $f$ to the original section 178 provided that an oral agreement might also be enforced on the basis of an estoppel to assert the bar of the statute. Such an estoppel might be

84. U.C.C. \& 2-205 comment 3 provides: "If supported by consideration [the offer] may continue for as long as the parties specify. This section deals only with the offer which is not supported by consideration."

85. One court has suggested that an offer not expressly "firm" cannot be made irrevocable by reliance, apparently concluding that to hold otherwise would be to override the express statutory requirement of $\S 2-205$. Ivey's Plumbing \& Elec. Co. v. Petrochem Maintenance, Inc., 463 F. Supp. 543, 551 n.4 (N.D. Miss. 1978) ("we reject the contention that a 'firm offer' may arise by implication from the mere fact of the buyer's reliance thereon to his detriment"). Such a position seems too formalistic in the light of Drennan v. Star Paving Co., 51 Cal. 2d 409, 333 P.2d 757 (1958), and many similar decisions. Reliance that is reasonable when an offer is expressly "firm" should not be per se unreasonable when the offer is silent on the point and preacceptance reliance by the offeree is reasonably foreseeable. However, explicit language expressing the possibility of revocation at any time could make such reliance appear to be unreasonable; in that case no injustice would be deemed to result from upholding the revocation.

86. Restatement $\S \S 197$ ("part performance" in land cases), 198 (full performance by one party to a contract not performable within a year) \& 355 (restitution generally available from one in default under a contract within the Statute of Frauds).

87. The corresponding sections in Restatement (Second) are $\S \S 129,130(2) \& 375$.

88. Restatement (Second) $\S 129$ is not explicitly limited to protection of plaintiff's restitution interest, however; it provides that specific performance can be granted where money damages for restitution are an inadequate remedy to avoid injustice. See id. comment d, illustrations 6-10. 
grounded on either "a misrepresentation there that there has been . . . satisfaction" of the statute by the execution of a signed memorandum, or on "a promise to make a memorandum"; in either case "substantial action[ ] taken in reliance" thereon would be required. ${ }^{89}$ This inconspicuous comment thus made two significant points: that a purely oral agreement might be enforceable because of reliance on an (equally oral) representation that a writing did exist; and that a mere promise to execute a writing in the future might be binding if relied on even though the person receiving and relying on such a promise could be under no illusions about the present existence of such a writing. What form such reliance might take, comment $f$ did not volunteer.

There is no counterpart in the new Restatement to old section 178's comment $\mathrm{f}$. Instead, the comment to new section 110 (section 178's successor) provides cross-references to section 129 (the successor to former section 197) ${ }^{90}$ and to a new section, 139.

\section{Section 139. ENFORCEMENT BY VIRTUE OF ACTION 1N RE- LIANCE.}

(1) A promise which the promisor should reasonably expect to induce action or forbearance on the part of the promisee or a third person and which does induce the action or forbearance is enforceable notwithstanding the Statute of Frauds if injustice can be avoided only by enforcement of the promise. The remedy granted for breach is to be limited as justice requires.

(2) In determining whether injustice can be avoided only by enforcement of the promise, the following cirumstances are significant:

(a) the availability and adequacy of other remedies, particularly cancellation and restitution;

(b) the definite and substantial character of the action or forbearance in relation to the remedy sought;

(c) the extent to which the action or forbearance corroborates evidence of the making and terms of the promise, or the making and terms are otherwise established by clear and convincing evidence;

(d) the reasonableness of the action or forbearance;

(e) the extent to which the action or forbearance was foreseeable by the promisor.

New section 139 appears to have substantial support in the cases, ${ }^{91}$ and to be an appropriate extension of comment f's earlier, more limited, application of the estoppel principle to Statute of Frauds cases. The language of section 139 obviously tracks that of section 90 but, as its comment points out, it applies to promises supported by consideration as well as some that are not. Indeed, this

89. Restatement § 178 comment f (1932).

90. See notes $87 \& 88$ supra.

91. See e.g., Janke Constr. Co. v. Vulcan Materials Co., 386 F. Supp. 687, 697 (W.D. Wis. 1974); McIntosh v. Murphy, 52 Hawaii 29, 469 P.2d 177 (1970); Walker v. Ireton, 559 P.2d 340 (Kan. 1977). These cases refer to Restatement $\S 217 \mathrm{~A}$, which has been renumbered $\S 139$ in the final version of the Restatement (Second). 
reflects the distinctive feature of new section 139-estoppel here does not supply a missing element of substance, but one of form. Since the policy at stake is that of the Statute of Frauds, the court should be particularly wary of possibly faulty recollection or outright deception on the part of the promisee seeking enforcement. Section 139 addresses this latter point in subsection (2)(c), which calls on the court to look to the circumstances of the reliance for corroboration of the making of the promise.

In another respect, however, enforcement of a promise might seem easier to obtain under section 139 than under section 90. Typically, a promisee invokes section 90 to obtain enforcement of a promise for which no "consideration" has been paid; although its enforcement may be necessary to compensate the promisee for unbargained-for reliance, enforcement may leave the promisor with a net loss unless that reliance itself has brought the promisor some benefit in exchange for the promised performance. Thus, the drafters of the revised Restatement have left open the possibility of sometimes limiting the section 90 remedy to only the amount necessary to compensate the promisee for his reliance; in this way the burden on the promisor of having to perform what may have been an essentially gratuitous promise is decreased. In the typical Statute of Frauds case, however, the underlying transaction is a "contract" supported by consideration, and the bar to its enforcement is not the absence of an exchange relationship but the fear that the plaintiff may be attempting to bold the defendant to an agreement never truly made. If the policy of the Statute of Frauds has been satisfied by clear and convincing proof, corroborated by the plaintiff's reliance, should not the "exchange" nature of the now enforceable agreement prompt the court to award the "normal" expectation remedy?

With the question stated that way, the answer might at first appear to be, yes, it should. That is not the result suggested by the drafters of section 139, however. Subsection 139(2)(a) urges the court to consider the "availability and adequacy of other remedies, particularly cancellation and restitution." Comment $\mathrm{d}$ is even more specific and restrictive: "Where restitution is an adequate remedy, other remedies are not made available" by the rule of section 139 . Comment $d$ also suggests that im some cases-presumably those in which the injury to the plaintiff's reliance interest is greater than the benefit to the defendant from any partial performance- - "it may be appropriate to measure relief by the extent of the promisee's reliance rather than by the terms of the promise." Thus, it may require unbargained-for and non-promisor-enriching reliance to activate section 139 at all, and, even then, full enforcement of the expectation may not be forthcoming. Whether the decisions will be so restrictive remains to be seen: if a court is convinced that the plaintiff's story is true, it may be inclined to give him the full benefit of the oral bargaim, ${ }^{92}$ particularly if estimating the amount of

92. For example, in one Hawaiian case the trial court had ruled that plaintiff's asserted oneyear contract of enployment fell outside the Statute of Frauds; it rendered judgment on the jury's verdict for what appears to have been full expectation damages (over $\$ 12,000$ ). The Supreme Court of Hawaii affirmed on the basis of promissory estoppel, invoking Restatement (Second) $\$ 217 \mathrm{~A}$ (Tent. Draft No. 4, April 25, 1968) (now Restatement (Second) § 139). McIntosh v. Murphy, 52 Hawaii 29, 469 P.2d 177 (1970). The court nowhere suggested that plaintiff should have been limited to his "reliance damages" (which presumably would have been primarily the costs of relocating first to Hawaii and then back to California). 
plaintiff's reliance is unduly difficult or would lead to inadequate relief in the light of intangible reliance costs.

As with the firm offer problem, it seems desirable to consider the interplay of the proposed Restatement rule concerning the Statute of Frauds and the relevant provisions of the Uniform Commercial Code. Section 139 is designed to overcome the effect of what would otherwise be an applicable and dispositive Statute of Frauds. Should its rule be used to avoid the effect of the Statute of Frauds contained in the Uniform Commercial Code? There is some suggestion in the caselaw that it should not-that the reliance of either party will not effect the rule of U.C.C. section 2-201.93 Since Statutes of Frauds have always been judicially narrowed, this seems an unwarranted (albeit self-imposed) limitation on the power of the court. It may stem in part from the fact that the Code's modern version of the Statute of Frauds provides the wary party with techniques for achieving enforceability unavailable under the Statute of Frauds in its traditional form. ${ }^{94}$ However, the drafters of the Restatement (Second) have been careful to refer to (and adopt, wherever that seemed appropriate) principles of the U.C.C.; and if they had intended to defer to the Code in section 139 it is reasonable to assume that they would have done so explicitly.95

As noted above, the first Restatement limited its exception to the defense of the Statute of Frauds to cases where the promisee had relied on either a misrepresentation that the statute had been complied with, or a promise that it would be. ${ }^{96}$ That earlier, limitcd exception was omitted from the revision of section 178 (now section 110) and its comments, and new section 139 nowhere refers to it. Section 139 has four illustrations, however, two of which appear to call for full enforcement of the oral agreement. Both of those illustrations involve an

93. See, e.g., Farmland Serv. Coop, Inc. v. Klein, 196 Neb. 538, 244 N.W.2d 86 (1976); But see Farmers Elev. Co. v. Lyle, 238 N.W.2d 290 (S.D. 1976). Although U.C.C. \$ $2-201$ contains no express exception for action in reliance, \$2-209(5) does provide that an oral modification agreement may be enforced notwithstanding the Statute of Frauds where a "Inaterial change of position" makes retraction by the other party "unjust."

94. Between merchants, U.C.C. § 2-201(2) enables one party to an oral contract to send a written confirmation to the other; if written objection is not made by the recipient within ten days, the sender of the confirmation may thereafter assert the oral contract notwithstanding the absence of any writing signed by the other party. In C.G. Campbell \& Son v. Comdeq Corp., 586 S.W.2d 40 (Ky. Ct. App. 1979) the court declined to make a judicial exception to $\$ 2-201$, pointing out that $\S$ 2-201(2) provides "its own statutory method of alleviation of hardships caused by $\$ 2$ 201(1)." Id. at 41. In Warder \& Lee Elevator, Inc. v. Britten, 274 N.W.2d 339 (Iowa 1979), the court relied on U.C.C. § 1-103 as authorizing the application of promissory estoppel under § 2-201, quoting and following Restatement (Second) $\$ 139$ (§ 217A in Tent. Draft No. 4, April 25, 1968). The issues are well drawn by the majority and dissenting opinions in that case: Chief Judge Reynoldson's dissent argues forcefully against the majority's willingness to contemplate general reliance upon oral agreements - with enforcement based solely on the buyer's subsequent contract to resell - in "initial purchases of agricultural products, probably Iowa's largest economic marketplace and involving almost three billion dollars worth of goods each year." Warder \& Lee, at 345. It is interesting to note that many of the cases in which promissory estoppel has been invoked under U.C.C. $\$ 2-201$ have involved sales of grain by growers to grain elevator corporations, which purchase for resale. In addition to the Warder \& Lee case, see cases cited in note 93 supra.

95. The only mention of the U.C.C. in \$ 139 or its comments is a simple reference to U.C.C. $\$ \S 2-201(3)$ \& 8-319(b), both of which permit enforcement in cases of partial performance.

96. See Restatement $§ 178$ comment f; text accompanying note 89 supra. 
express promise by the defendant to execute a writing sometime in the future. ${ }^{97}$ Although this factor is not reflected in the text of section 139, these illustrations could be read to imply that such a promise is still a requisite to the application of promissory estoppel in Statute of Frauds cases. This implication seems unwarranted, however; if the drafters of section 139 intended only to highlight comment $f$ to former section 178 , they could have made their point much more clearly and with greater economy. Although some current caselaw suggests that the rule of comment $f$ to former section 178 is as far as a court should go in overriding the policy of the Statute of Frauds, ${ }^{98}$ section 139 surely is not intended to suggest so narrow an approach; it is to be hoped that courts will not so read it.

\section{Reliance on a Promise That Modifies a Prior Agreement: Sections 89 and 150.}

Section 89 of the Restatement (Second) ${ }^{99}$ recommends an altered judicial attitude toward agreements that modify already-existing contracts. This new section is another of those that reflect the influence of the Uniform Commercial Code, and, like section 87, it deals with more than reliance. Nevertheless, section 89 directly addresses the role of reliance in an important part of the contracting process, and therefore merits discussion here.

The section suggests three different bases for enforcing a promise to modify a preexisting executory contract: the "fair and equitable" nature of that new promise in the light of unanticipated circumstances; the effect of a statute; or "a material change of position" on the part of the promisee "in reliance on the promise." The drafters here attempt to reconcile the revised Restatement's rule both with developments in the common law and with policies of the Uniform Commercial Code. To understand section 89 , it is therefore necessary to recall briefly the recent history of the familiar "preexisting duty" rule, a corollary of the general rule requiring consideration for the enforcement of an executory promise.

97. The two illustrations are based on Vogel v. Shaw, 42 Wyo. 333, 294 P. 687 (1930), and Alaska Airlines, Inc. v. Stephenson, 217 F.2d 295 (9th Cir. 1954). In the former case, the defendant's promise to "turn over" or "give" certain leases to plaintiff presumably contemplated a written assignment, but the court's discussion places little emphasis on that point. In the latter, the defendant expressly promised to execute a written employment contract, and the court cited Restatement $\$ 178$ comment $f$ im support of its decision.

98. See, e.g., "Moore" Burger, Inc. v. Phillips Petrol. Co., 492 S.W.2d 934, 940 (Tex. 1973) (on motion for rehearing); Boddy v. Gray, 497 S.W.2d 600, 604-05 (Tex. Civ. App. 1973).

99. Restatement (Second) 89, "Modification of Executory Contract" provides:

A promise modifying a duty under a contract not fully performed on either side is binding

(a) if the modification is fair and equitable in view of circumstances not anticipated when the contract was made; or

(b) to the extent provided by statute; or

(c) to the extent that justice requires enforcement im view of material change of position in reliance on the promise. 
At common law, an agreement to modify an existing contract, like any other agreement, required consideration in order to be binding; a "one-sided" modification - one that changed the duty of one party but left that of the other unaffected-would be held unenforceable. ${ }^{100}$ The party adversely affected by such a modification could therefore refuse to be bound by it, and insist upon the terms of the original agreement. ${ }^{103}$ This common law rule has been defended on the ground that it deters the abuse of power that can result when one party, having begun to perform, extorts an increased performance from the other, where it is unlikely that the other party can obtain a completely satisfactory substitute quickly enough to avoid unrecoverable damage. ${ }^{102}$ But the common law rule has two glaring flaws. First, it opens the way for another kind of abuse-the abuse that can be practiced by one who apparently assents to the modification of an existing contract, knowing that he can repudiate it with impunity. Second, the rule runs counter to what any reasonable layperson would intuitively expect the rule of law to be: if two persons, legally competent, can bind themselves to a contract and set its terms, why cannot the same two persons modify that contract by another equally binding agreement?

Faced with a rule that produces such mixed results-sometimes deterring extortion; sometimes rewarding duplicity - the common law has responded, typically, by fashioning exceptions that will produce fairer results in specific cases where the old rule works poorly, while retaining the rule for use in cases where it works well. Thus, one line of cases upholds one-sided modifications where fairness and changed circumstances justify them. ${ }^{103}$ Another body of precedents suggests that a court may choose to uphold a one-sided modification if the parties have gone through a ritual "rescission" of the old contract. ${ }^{104}$ And, of course, a court may uphold an apparently fair modification agreement by seizing upon some slight detriment or benefit that it can characterize as consideration. ${ }^{105}$

The Uniform Commercial Code, on the other hand, takes a diametrically opposite view of the potential utility of modifying agreements. Section 2-209(1) simply abolishes the requirement of consideration in such cases (while at the same time preserving for the court the option of refusing to enforce such an agreement if it should appear to be the result of "bad faith" ${ }^{106}$ ). The Code

100. See Restatement $\$ 76(a) ;$ Restatement (Second) $\S 73$ comment c.

101. To the extent that the agreement would have been unenforceable only for lack of consideration, the party who received no consideration and yet performed fully would have no right to restitution, having given a kind of "gift." In some cases, a fully performed modification agreement might be avoidable on grounds of duress, and the aggrieved party entitled to restitution. See Restatement (Second) $\S \S 175,376$. Compare Austin Instrument, Inc. v. Loral Corp., 29 N.Y.2d 124, 272 N.E.2d 533, 324 N.Y.S.2d 22 (1971), with Tri-State Roofing Co. v. Simon, 187 Pa. Super. 17, 142 A.2d 333 (1958).

102. See, e.g., Lingenfelder v. Wainright Brewery Co., 103 Mo. 578, 15 S.W. 844 (1891),

103. See, e.g., King v. Duluth, M. \& N. Ry., 61 Minn. 482, 63 N.W. 1105 (1895).

104. See, e.g., Schwartzreich v. Bauman-Basch, Inc., 231 N.Y. 196, 131 N.E. 887 (1921).

105. See, e.g., Commonwealth Inv. Co. v. Fellsway Motor Mart, Inc., 294 Mass. 306, 1 N.E.2d 201 (1936) (promise to occupy premises sufficient consideration although promise not to break lease would not be).

106. See U.C.C. $\S \S 1-203,2-209$ comment 2. 
recognizes that businesses modify continuing contracts every day and commonly regard themselves as bound by modifying agreements. Sometimes such a modification involves give-and-take on both sides; sometimes it represents a "onesided" concession, reasonably requested and freely given. In either case, the Code views the modifying agreement as presumptively valid, to be upset only if it appears to be the product of unfair pressure and extortive tactics that the other side had little power to resist. U.C.C. section 2-209 sounds two caveats, however: the contract as modified may be governed by the Code's Statute of Frauds; ;07 and the original written contract may itself provide that no modification shall be binding unless in writing and signed. ${ }^{108}$ In either case, if the modification agreement fails to meet that formal requirement, it is not deemed immediately and finally binding; rather, it constitutes a "waiver," which may become nonretractable if one party materially changes position in reliance thereon, making subsequent retraction by the other party "unjust." 109

One suspects that the drafters of the revised Restatement might have preferred to follow the Code's approach on this point and simply to eliminate the consideration requirement for contract modification. In any event, they apparently tried in section 89 to do the next best thing-to (a) push the common law rule on consideration as close as possible to the Code's without abolishing the requirement altogether, (b) point out the possibility of statutory abolition, and (c) provide still another basis for binding modifications in cases where substantial reliance is generated. One can hardly quarrel with (b); it would clearly be true whether or not the Restatement so provided. Both (a) and (c) deserve some examination, however.

The drafters have suggested, in comment $b$ to section 89 , that the preexisting duty rule, now set forth in section 73 , finds a principal justification in cases involving promises "induced by unfair pressure." The cominent explains that the proposed new rule of section 89(a) requires more than an "absence of coercion"; it demands that the proponent of the modification supply "an objectively demonstrable reason for seeking a modification." It then invites the reader to "compare" the comment to U.C.C. section 2-209. If the implication is that the new section 89(a) as explained by this comment tracks the policy of section 2-209(1), as explained by its comment, then that is somewhat misleading. Comment 2 to U.C.C. section 2-209 does indeed state that "extortion of a 'modification' without legitimate commercial reason is ineffective as a violation of the duty of good faith." ${ }^{110}$ But comment 2 also observes that since "good faith" includes "reasonable commercial standards of fair dealing in the trade," this may "in some situations require an objectively demonstrable reason for seeking nodification." "m Here, then, is a difference worth noting, I believe. The Code treats a modification freely agreed to as presumptively benign. The party seeking

107. U.C.C. \& 2-209(3).

108. U.C.C. $\S 2-209(2)$. Such an agreement would have been ineffective under pre-Code law. Corbin, Contracts 1295 (1952).

109. U.C.C. \& 2-209(5).

110. Emphasis supplied.

111. Emphasis supplied. 
to avoid it has the burden of showing that it was "extorted" by the other party, acting in bad faith. It is true that "in some situations" an "objectively demonstrable reason" will enable the proponent of the modification successfully to counter such a claim of bad faith. But in other cases, the parties will have agreed to the modification, because people in business make concessions they regard as relatively minor in the imterest of preserving a long-term relationshipnot because their arms are twisted, but simply because the other party proposes them and there seems to be no strong reason to object. Such a modification should be binding and enforceable under U.C.C. section 2-209(1). ${ }^{112}$ The difference between the Code and the new Restatement on this point may be little more than a question of the burden of proof; nevertheless, the drafters of cominent $b$ to Restatement section 89 should not be permitted by implication to blur the distinct shift that the drafters of the Code have made away from technical rules of consideration and toward the enforcement of business agreements freely made. ${ }^{113}$

In order to assess the effect of the third ground for enforcement provided in section 89 , the possibility of reliance as set forth in subsection (c), it is necessary to examine also the provisions of Restatement (Second) section 150. ${ }^{114}$ This section does in the context of the Restatement precisely what section 2-209(5) does in the Code: it provides a doctrinal basis for binding one party to an oral modification ("one-sided" or not-both rules appear to be indifferent on that point ${ }^{15}$ ) that could otherwise be avoided because it fails to satisfy the formal requirements of the Statute of Frauds. ${ }^{116}$ Both sections 89(c) and 150 of the revised Restatement, then, address the possibility that reliance will render enforceable and binding an agreement to modify a preexisting contract, even though, absent reliance, that agreement would ordinarily be unenforceable because of another rule of law. The two sections differ, however, as to the conflicting policy at stake. In the case of section 150 , the conflicting policy is that of the Statute of Frauds. Section 89, however, has nothing to do with the formal requirement of the Statute of Frauds; its competing policy is one of substance: the doctrine of consideration. Whether the drafters' invocation of U.C.C. section

112. See J. White \& R. Summers, Handbook of the Law Under the Uniform Commercial Code 44 (2d ed. 1980); id., at 44 n.56 (citing cases). See also Gulf Chem. \& Metallurgical Corp. v. Sylvan Chem. Corp., 122 N.J. Super. 499, 300 A.2d 878 (1973).

113. For a more critical view of the U.C.C.'s approach to contract modification, see Hillman, Policing Contract Modifications under the UCC: Good Faith and the Doctrine of Economic Duress, 64 Iowa L. Rev. 849 (1979).

114. Restatement (Second) $§ 150$, "Reliance on Oral Modification," provides:

Where the parties to an enforceable contract subsequently agree that all or part of a duty need not be performed or of a condition need not occur, the Statute of Frauds does not prevent enforcement of the subsequent agreement if reinstatement of the original terms would be unjust in view of a material change of position in reliance on the subsequent agreement.

115. At least one writer suggests that U.C.C. § 2-209(3) applies only to modifications unsupported by consideration. EisIer, Oral Modification of Sales Contracts Under the Uniform Commercial Code: The Statute of Frauds Problem, 58 Wash. U.L.Q. 277 (1980).

116. In addition to providing a basis for enforcing a promise to modify despite the application of the Statute of Frauds as provided in § 2-209(3), U.C.C. \$ 2-209(5) provides a means of overcoming the bar of a "private Statute of Frauds" validated by $\$ 2-209(2)$. 
2-209(5) to buttress section 89 (c) ${ }^{117}$ is ingenious or ingenuous is difficult to say, but it is clearly inappropriate.

As we.have seen, the revised Restatement approaches reliance that can overcoine an absence of consideration (section 90) somewhat differently from reliance that can overcome the Statute of Frauds defense (section 139). In the case of a gratuitous promise, the law is pursuing a substantive ground for enforcement; in the Statute of Frauds context, the law is seeking reassurance that the promise it enforces was actually made. Neither section 89 (c) nor section 150 directly grapples with this distinction, however.

In comment $\mathrm{d}$ to section 89 , the drafters do little more than acknowledge their misplaced debt to U.C.C. section 2-209(5); they shed no light on the nature of the reliance that will have the stated effect. The comment does provide three illustrations, however. The first, a promise to extend an insurance policy, is a case more of mistake than of modification; the third involves no change of position. The second, illustration 7, involves a lessor's agreement to accept a lower rent under an existing long-term lease because of "war conditions" that apparently produce vacant apartments in the landlord's building and also impair the existing lessee's ability to pay his original, higher rent. After the war is over, the apartments are again fully rented, and the lessor notifies the tenant that the rent is being restored to the original figure. The suggested result on these bare facts is that the lessee must pay the higher rent "only from a reasonable time after the receipt of the notification." Apparently, then, the modification that lowered the rent was binding, but only until retracted; the drafters have not indicated what acts of reliance would be sufficient to make the reduction permanent. ${ }^{118}$

Thus, section 89 of the revised Restatement provides no guidance on the question of what kind of reliance is necessary to make a "one-sided" modification agreement binding and nonretractable. In the light of the indifference shown by U.C.C. section 2-209(1) to the consideration requirement, and the seeming sympathy of the Restatement's revisers for that position, it might be argued that merely continuing to perform under the contract as modified will constitute section 89(c) reliance. This would create a possible paradox: although performance

117. Restatement (Second) $\$ 89$ comment.

118. The questions raised by illustration 7 on this point are not resolved by examining the cases offered in support of its principle. The case on which it is expressly modeled, see Restatement (Second) $\S 89$ comment d, reporter's note, is Central London Property Ltd. v. High Trees House Ltd., [1947] 1 K.B. 130. In that case, the principal ground of decision was that the parties' agreement to reduce the rent was in fact intended to last only so long as the war conditions obtained. The court indicated that an estoppel could hold the lessor to its promise, and suggested that if the agreement were binding on an estoppel basis, it might have lasted as long as the parties intended, stating: "I prefer to apply the principle that a promise intended to be binding, intended to be acted on and in fact acted on, is binding so far as its terms properly apply. "Id. at 136 (emphasis supplied). Other cases cited in support fail to reach the question of the degree of reliance necessary to prevent retraction of a gratuitous modification. In McKenzie v. Harrison, 120 N.Y. 260,24 N.E. 458 (1890), the court found that an agreement to reduce the rent "until times are better" was binding so far as the reduced rent had been paid and received, on the theory of executed gift. In Liebreich v. Tyler State Bank \& Trust Co., 100 S.W.2d 152 (Tex. Ct. Civ. App. 1936), the court held that the existence of a general economic depression furnished a reason for making the rent-reduction agreement binding, mvoking the "unanticipated difficulty" line of cases. 
of a "preexisting duty" does not qualify as consideration, it may constitute detrimental reliance. However, illustration 7 to Restatement (Second) section 89 seems to suggest that something more is needed. If the tenant in the illustration, in reliance on an open-ended promise of lowered rental, had foregone an opportunity to surrender its lease and relocate in another building at a lower rental, would that act of reliance be sufficient to preclude the landlord's later reversion to the higher rent? Alas, the drafters have left us to fend for ourselves.

For its part, section 150 is not much more helpful in defining the kind of reliance on an oral inodification agreement that will overcome the defense of the Statute of Frauds. Its illustrations deal primarily with the possibility that one party will orally agree to waive, or at least to delay, satisfaction of a contractual condition, naturally inducing the other party to refrain from performing that condition, or to perform it tardily. ${ }^{119}$ Since such failure or delay is not a breach, if the condition cannot now be complied with, it cannot be reinstated. ${ }^{120}$ This illustration is useful, but there are other cases involving oral modification that the drafters did not address. Suppose a sales agent is employed by a manufacturing business for an eighteen-1nonth period, under a written contract providing for compensation consisting of a monthly salary of $\$ 2,000$ plus a commission of three percent on sales. After three months, the president of the company orally proposes that the terms of employment be changed to $\$ 1,500$ per month and a commission of four per cent; the einployee accepts. ${ }^{121}$ During the following month the employee continues to perform as a sales agent, generating sufficient sales to entitle her to considerably higher compensation under the new formula. Can the employer successfully resist an obligation to compensate her at the new rate, on the ground that she only performed her regular duties under the original agreement, and therefore did not detrimentally rely on the oral modification? What if these sales resulted from greater efforts on her part? Comment $d$ to section 150 explains only that to prevent retraction of the "waiver," there must be "a change of position in reliance on the modifying agreement, ... such that reinstatement of the original terms would be unjust." This is no more helpful than it is controversial. The best that can be said for the Restatement's treatment of this point is that its drafters have provided no less guidance than did the drafters of U.C.C. section 2-209(5), to which they have again been careful (this time appropriately) to refer.

\section{The Role of Reliance in the Common Law of CONTRACTS: Further ObSERvations}

The sections of the revised Restatement of Contracts cited and discussed above are by no means the only ones that in some way reflect the important part played in the law of contract by the concept of reliance. In several sections and

119. E.g. Restatement (Second) $§ 150$ illustration 1.

120. The same principle is reflected in Restatement (Second) $\$ 84(2)$.

121. Of course this modification is supported by consideration, but the agreement as modified would still fall within the one-year clause of the Statute of Frauds. 
comments the drafters have made more explicit the reliance-protecting policy that underlay a rule articulated in the original Restatement. ${ }^{122}$ Elsewhere, they have expanded the role reliance plays in creating or affecting rights of the parties to a contract. ${ }^{123}$ Although the treatment of "reliance damages" is only partially developed, ${ }^{124}$ there is additional recognition that reliance by one party, whether or not it amounts to performance in whole or in part, may affect the availability, nature, or size of his remedy. ${ }^{125}$

In recent years, the concept of promissory estoppel has been employed with increasing frequency in contract litigation, and the revised Restatement accurately reflects that fact. Some courts have exhibited difficulty in distinguishing between reliance as a basis for the enforcement of promissory obligations and the various other doctrines of contract law; ${ }^{126}$ it is to be hoped that the revised Restatement will lessen much of that confusion.

Useful as they are, however, the revised Restatement's additional variations on the theme of promissory estoppel-as exemplified by sections 87 and 139do no more than indicate the current high-water mark of reliance theory being applied in contract cases. The tide is still coming in, and we can confidently expect additional applications in the future. For example, the original Restate-

122. See, e.g., Restatement (Second) $\S 38$ comment a. The comment explains that a rejection terminates a power of acceptance because the offeror is likely to rely on its apparent finality, both by making alternative arrangements and by refraining from communicating an express revocation. See also $\S 69(1)$ (c) comment c (pointing out that an offeree may affirmatively rely on the offeror's statement that silence will constitute an acceptance by refraining from communicating an express acceptance, and in other positive ways; such reliance is protected by the rule of that section).

123. See, e.g., Restatement (Second) $\S \S 88$ (c) (reliance on a promise of suretyship); 273 (c) (reliance on assent to a present discharge).

124. New $\S 349$ permits the injured party to recover damages based on his reliance interest. Unlike its predecessor, § 333 of the original Restatement, $\S 349$ does not expressly limit the injured party's damages to "the full contract price promised by the defendant"; see Restatement $\S 333$ (a). However, that primciple is still reflected in Restatement (Second) $\S 349$ comment a: "If the injured party's expenditures exceed the contract price, it is clear that at least to the extent of the excess, there would have been a net loss. For this reason, recovery for expenditures under the rule stated in this section may not exceed the full contract price." Thus, the drafters have once again failed to distingtish between "essential" and "incidental" reliance. See Fuller \& Perdue, The Reliance Interest in Contract Damages, 46 Yale L.J. 52, $89-96$ (1936). Nevertheless, Restatement (Second) \& 349 reporter's note cites with apparent approval Security Stove \& Mfg. Co. v. American Ry. Express Co., 227 Mo. App. 175, 51 S.W.2d 572 (1932), the classic case for awarding damages far in excess of "the contract price," based on incidental reliance.

125. Restatement (Second) defines a "forfeiture" as "the denial of compensation that results when the obligee loses his right to the agreed exchange after he has relied substantially, as by preparation or performance on the expectation of that exchange." Restatement (Second) $\$ 229$ comment b (emphasis supplied). The general policy of avoiding or minimizing such "forfeiture" is frequently reflected in the revised Restatement; see, e.g., $\$ \$ 197,227 \&$ comment b, 241(c). See also $\S 370$ (noting that a duty of restitution may possibly arise by virtue of an act of reliance that, although not amounting to "performance," benefits the other party); §373 illustration 4.

126. This sometimes results in confusing judicial decisions. In Kaye v. United States, 467 F.2d 415 (D.C. Cir. 1972), the court held that plaintiff employee had relied on defendant's implied promise to coinplete his security clearance with reasonable speed. However, if that promise was implicitly part of defendant's contract to employ plaintiff, then the court's reference to $\S 90$ was unnecessary. In Blatt v. University of S. Cal., 5 Cal. App. 3d 935, 85 Cal. Rptr. 601 (1970), the court blatantly misdescribes the well-known Hamer v. Sidway, 124 N.Y. 538, 27 N.E. 256 (1891), as "based upon the principle of promissory estoppel." Blatt v. Umiversity of S. Cal., 5 Cal. App. 3d at 943,85 Cal. Rptr. at 607. 
ment suggested only a limited role for promissory estoppel in defeating the historic Statute of Frauds defense. ${ }^{127}$ Although some courts are still unsure of its propriety, ${ }^{128}$ the broader application of promissory estoppel provided by new section 139 indicates an increasing willingness to subordinate form to substance, where justice requires. In the light of this development it seems inevitable that another bastion of form-over-substance, the parol evidence rule, ${ }^{129}$ eventually will fall under similar attack. If it is reasonable to rely on an entirely oral agreement, it must also be reasonable in some cases to rely on assurances that a writing is not necessary to preserve a particular term of agreement. ${ }^{130}$ Hints of this development have begun to appear in the caselaw, ${ }^{131}$ but it is clearly not yet ripe for inclusion in the Restatement of Contracts. Indeed, by its very nature, the principle stated in section 90 defies all attempts to confine it within rigid categories. Like two other grand principles, articulated in the U.C.C. and adopted by the drafters of the Restatement-"good faith" 132 and "unconscionability" ${ }^{133}$ _."promissory estoppel"' states a principle of abstract justice capable of application in an infinite variety of factual situations. ${ }^{134}$ Promissory estoppel focuses precisely on a particular kind of "wrongdoing"-the making and subsequent breaking of a promise, where it was (or should have

127. See text accompanying note 89 supra.

128. See cases cited in note 98 supra.

129. See generally Restatement (Second) $\S \S 209-218$.

130. In West Los Angeles Inst. for Cancer Research v. Mayer, 366 F.2d 220 (9th Cir. 1966), plaintiff had entered into a sale-and-leaseback agreement with the hope of achieving substantial tax benefits; it later sought to rescind on the ground that such benefits would not be forthcoming because of a change of policy by the Internal Revenue Service. The court awarded plaintiff the relief requested, on the theory of "frustration of purpose." However, the parties had foreseen the possibility of precisely this frustrating event, and the plaintiff had sought to include an express provision in the written contract to cover it. The defendant had resisted this request on the ground that the danger of adverse tax agreement would thereby be increased, but had orally agreed to rescind if the event did occur. The court's decision therefore seems better justified if viewed as a protection of reasonable, detrimental reliance on an oral promise. See Knapp, Problems in Contract Law 480-482 (1976). In Bussard v. College of St. Thomas, 294 Minn. 215, 200 N.W.2d 155 (1972), plaintiff Father Bussard, a former partial owner (seller) of the magazine "Catholic Digest," claimed that he had been promised continued employment as its publisher after the sale. The written sales contract, however, contained no such promise. The appellate court held that in the light of the ecclesiastical relation of the various persons involved, the plaintiff might not have insisted that such a promise, made orally, be incorporated in the writing, and the written contract could therefore be viewed as only a partial integration of the agreement of salc. An equally plausible rationale for the decision would be that plaintiff was justified in relying on the oral promise, despite its omission from the written agreement, by the relationship of the parties and by the fact that the promise was apparently offered freely and not as part of the bargaining over the terms of sale. Cf. J.C. Millett Co. v. Park \& Tilford Distillers Corp., 123 F. Supp. 484, 488 (N.D. Cal. 1954) (plaintiff's reliance on defendant's oral promise to retain plaintiff as distributor "so long as they did a satisfactory job" held to create an obligation not to terminate until a reasonable time- one year-had passed, despite defendant's express refusal to enter imto a written agreement protecting plaintiff against termination).

131. Sec, e.g., Ehret Co. v. Eaton, Yale \& Towne, Inc., 523 F.2d 280, 283-84 (7th Cir. 1975), cert. denied, 425 U.S. 943 (1976).

132. U.C.C. \$§ 1-201(19), 2-103(1); Restatement (Second) § 205.

133. U.C.C. \& 2-302; Restatement (Second) § 208.

134. Indeed, the open-ended and indefmite nature of the U.C.C.'s concept of "unconscionability" has been criticized by some commentators, notably Professor Arthur Leff in a well-known article. See Leff, Unconscionability and the Code-The Emperor's New Clause, 115 U. Pa. L. Rev. 485 (1967). 
been) foreseeable that the promisee would detrimentally rely. Unlike "good faith" or "unconscionability," therefore, promissory estoppel is not a doctrine intended to erect a shield against duress, coercion, or other forms of overreaching by the stronger party that are apparent to the weaker party at the time. ${ }^{135}$ Rather, it properly belongs with such concepts as "fraud," "fiduciary duty," and "equitable estoppel," which counter the abuse of a relation of trust and confidence, often-but not always-accompanied by deliberate deception.

The principle that a trust reasonably reposed and voluntarily accepted should not be violated without remedy is a very old one; section 90 is but one of its formulations. Perhaps because of its excellent drafting, however, it has been an unusually influential one. The revised Restatement provides a useful summary of the current status of the section 90 principle, but it is not likely to be the end of the story. Indeed, by the time its force is fully felt, section 90 may well have transformed the face of contract law in ways undreamt of by its drafters-or its revisers.

135. Cf. Restatement (Second) $\S 208$ comment d ("unconscionability" stems from "gross inequality of bargaiming power" together with "terms unreasonably favorable tc the stronger party," and may involve "deception or compulsion"). 